\begin{tabular}{|c|}
\hline $\begin{array}{l}\text { Article ID: } 5523 \\
\text { DOI: } 10.5586 / \mathrm{am} .5523\end{array}$ \\
\hline $\begin{array}{l}\text { Publication History } \\
\text { Received: } 2020-06-15 \\
\text { Accepted: } 2020-07-05 \\
\text { Published: } 2020-12-28\end{array}$ \\
\hline $\begin{array}{l}\text { Handling Editor } \\
\text { Wojciech Pusz; Wrocław } \\
\text { University of Environmental and } \\
\text { Life Sciences, Poland; } \\
\text { https://orcid.org/0000-0003- } \\
\text { 1531-2739 }\end{array}$ \\
\hline $\begin{array}{l}\text { Funding } \\
\text { This work did not involve any } \\
\text { funding. }\end{array}$ \\
\hline $\begin{array}{l}\text { Competing Interests } \\
\text { No competing interests have } \\
\text { been declared. }\end{array}$ \\
\hline $\begin{array}{l}\text { Copyright Notice } \\
\text { ( The Author(s) } 2020 \text {. This is an } \\
\text { open access article distributed } \\
\text { under the terms of the Creative } \\
\text { Commons Attribution License, } \\
\text { which permits redistribution, } \\
\text { commercial and noncommercial, } \\
\text { provided that the article is } \\
\text { properly cited. }\end{array}$ \\
\hline
\end{tabular}

MEMORIES AND SCIENTISTS

\section{Prof. dr hab. Maria Dynowska, Full Professor}

\author{
Anna Biedunkiewicz $\mathbb{1}^{*}$ \\ Department of Microbiology and Mycology, Faculty of Biology and Biotechnology, University \\ of Warmia and Mazury in Olsztyn, Poland
}

*To whom correspondence should be addressed. Email: alibi@uwm.edu.pl

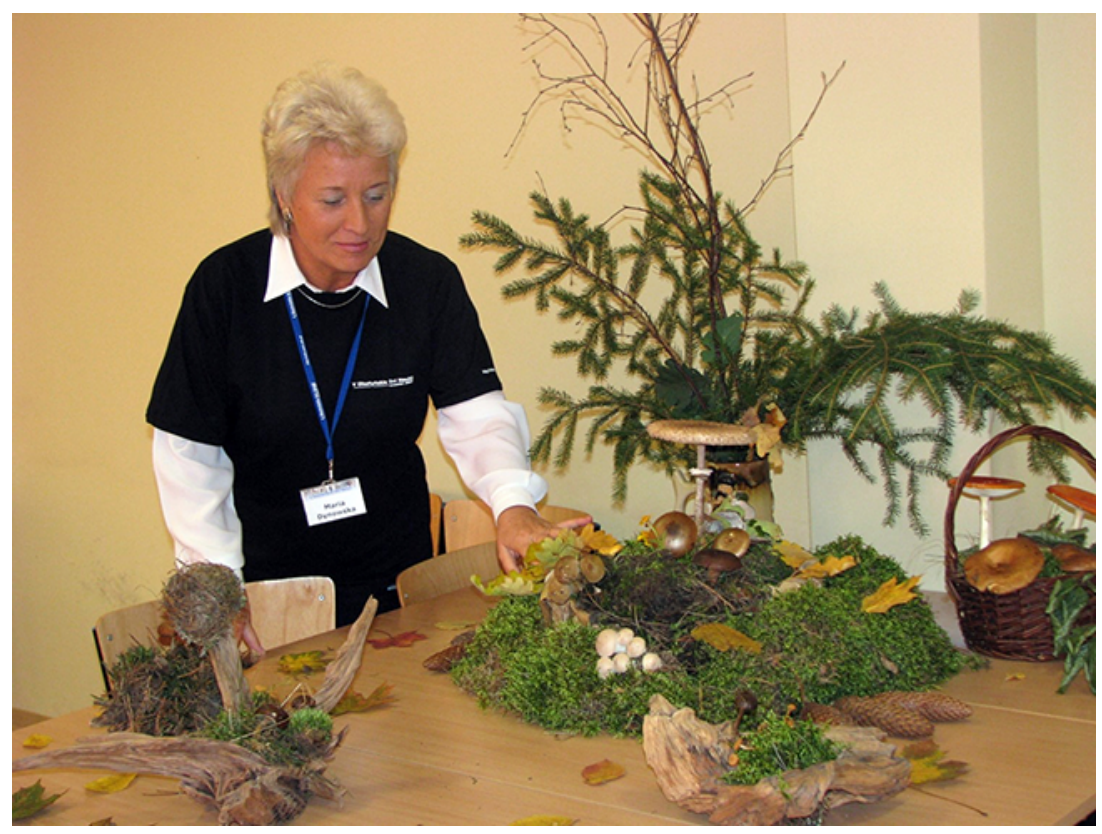

Professor Maria Dynowska (born January 23, 1949 in Przemyśl) graduated from the Faculty of Biology and Earth Sciences at Maria Curie-Skłodowska University in Lublin. She obtained the following degrees: master of biology (botany) in 1973, doctor of agricultural sciences (phytopathology) in 1981 from the School of Agriculture and Technology in Olsztyn, and doctor habilitated in biology (microbiology) in 1995 from the Faculty of Biology and Earth Sciences at the Nicolaus Copernicus University in Torun. She became a professor of biological sciences in 2003. Although she retired in 2019, she continues her scientific work.

Professor Maria Dynowska settled in Olsztyn in 1974 when she became an assistant, and then a senior lecturer, at the Department of Botany at the Institute of Biology and Environmental Protection at the Teachers College. After obtaining the title of doctor habilitated, she assumed the position of Head of the Unit, which in 1996 was transformed into the Unit of Mycology of the Teachers College and in 2004 (after the reorganization of university education in Olsztyn) into the Department of Mycology of the University of Warmia and Mazury in Olsztyn. Two research teams were established at the initiative of Professor Dynowska: The Team for Fungi and Lichens Monitoring and the Team for Medicinal and Applied Mycology. This was a consequence of the implementation of earlier research plans developed at the Department, oriented towards mycology in its broad sense and its links with other branches of science, especially phytosociology and geobotany, as well as phytopathology and medicine. However, the scientific accomplishments of the Department staff - the majority of whom earned their doctoral degrees under the supervision of Professor Maria Dynowska (dr hab. Anna Biedunkiewicz, dr hab. Dariusz Kubiak, dr Elżbieta Ejdys, and dr Ewa Sucharzewska) - were of the greatest importance. 
Professor Dynowska particularly valued interdisciplinary studies that focused on reservoirs and the bioecology of fungi - potential human pathogens - in different trophic systems, paying close attention to the variable nature of fungi and its consequences.

The scientific achievements of Professor Dynowska include papers on:

- Crop phytopathogens (studies of genus Typhula - unique in Poland) and phytopathogens with affinity to the skin and blood vessels (Fusarium solani, F. oxysporum);

- Common saprotrophs - commensals of the human skin and the alimentary tract, capable of causing severe surface and organ mycoses and lethal in extreme cases - in vulnerable patients (with cancer, TB, neutropenia, etc.);

- Natural reservoirs of potential anthropopathogens (e.g., aquatic ecosystems eutrophicated and polluted with household sewage, people with mycoses, fungi carriers, etc.);

- The use of some microfungi (Candida albicans, Trichosporon beigelii, Rhodotorula spp.) as indicators of water sanitary quality and epidemic threat; and

- Seeking to identify links of the mycosis epidemic chains (birds as mycoinfection vectors and sources).

The research conducted by Professor Dynowska has widespread applicability to the diagnostics of mycoses of the respiratory and alimentary tracts, increasing the affinity of fungi to human tissues and the growing drug resistance of the majority of fungi isolated from clinical materials. In the latter case, Professor Dynowska observed a correlation with an increase in the enzymatic activity in patients on chemotherapy, radiotherapy, and antibacterial antibiotic therapy.

The emphasis on medical mycology research conducted by Professor Dynowska was largely a consequence of her interest in medical science during her school education and studies. When she was offered an opportunity to cooperate with the Independent Public Unit for Tuberculosis and Pulmonary Diseases in Olsztyn, she accepted it without hesitation. She initially started working as a laboratory diagnostician and then as a consultant and a supervisor of specialty training in mycoses diagnostics and prevention.

The theoretical knowledge and practical experience gained at the hospital laboratory was introduced to the Department by Professor Dynowska and applied successfully in scientific research (e.g., by doctoral students from other centers) and in teaching.

It came as no surprise that a Nursing Unit was established at the Department of Mycology in 2002 under the management of Professor Dynowska, who hired medical staff and organized the research and teaching base of the nursing major - a novelty at the University (with European Union requirements regarding educating nurses in Poland). From this germinated the future Faculty of Medical Sciences. Professor Dynowska was deputy dean for the major during the 2003-2007 term, which created an even stronger bond between the Department and medicine and allowed for the expansion of scientific collaboration with physicians of different specialties (pulmonology, surgery, oncology, and gastroenterology).

Professor Dynowska's body of scientific achievement is rich and diverse. It has shone new light on the pathogenic potential of fungi that live on and in human bodies and emphasized the significant role of fungi in the environment along with bacteria. Professor Dynowska's work includes 227 publications, with 135 original and review papers and 92 research communications. She has delivered 10 lectures at plenary sessions and 82 reports at domestic and foreign scientific conferences. She has also been the editor of five monographs and has prepared a number of mycologic expert opinions for public institutions and sacral facilities, as well as reviews for publishing houses and scientific periodicals. She has been awarded grants from the Ministry of Science, National Science Centre, and National Centre for Research and Development. She has reviewed 20 doctoral theses, seven habilitation dissertations, and seven professorship proceedings. She also supervised 10 doctoral (there are two ongoing proceedings), 108 master's, and 16 bachelor's theses. 
Professor Dynowska is a member of three scientific societies: the Polish Botanic Society (since 2013: honorary member, 2007-2010: chairperson of the Mycology Section, three terms: chairperson of the Revision Committee); the Polish Mycological Society (founding member); and the Polish Phytopathological Society. She was a member of the Mycology Team at the Committee of Parasitology of the Polish Academy of Sciences from 1999 to 2015 and she has been a member of the Board of Editors of the Annals of Parasitology since 2013. She was appointed a member of the Committee of Organismal Biology of the Polish Academy of Sciences in 2015. She has been cooperating with numerous scientific centers in Poland and abroad. In 2018, she was appointed as an expert in microbiology for the Polish Accreditation Committee.

Professor Dynowska's scientific capabilities, perseverance, and determined actions closely correspond with her teaching and organizational skills and control over matters important to academic circles. She has always regarded didactic matters and methods of education as important. She has frequently highlighted the fact that while trying to accumulate as many points as possible, too little time is devoted to teaching and the truth is forgotten, resulting in improper teaching, which may consequently cause the depreciation of science.

Professor Dynowska's major teaching-related achievements include $(\boldsymbol{i})$ separating mycology from botany as a distinct, obligatory subject and introducing it in the following majors: biology (1990), biotechnology (2000), and microbiology (2013), and (ii) developing and adding 15 subjects in mycology to the syllabus in these majors, making it the richest offer in Poland. Now students express their greatest interest in phytopathology, medical mycology, applied mycology, hydromycology, lichenology, mycoses bioecology, hospital-acquired infections, edible and poisonous fungi, and mycosociology. Professor Dynowska's didactic activities include all forms of teaching at the I, II, and III degrees of studies, comprising lectures, seminars, auditory modules, laboratory and field classes, as well as specialty workshops for students of biology, biotechnology, microbiology, and, earlier, nursing.

Professor Dynowska's organizational activity is indisputable. Her above-mentioned achievements would not have been possible without her skills, professionalism, and commitment to this field, which has been recognized both at her parent university and elsewhere. This is demonstrated by numerous honors: 21 Rector's awards for scientific, didactic, and organizational achievements, the Gold Cross of Merit (2000), the Medal of the National Education Committee (2005), the Honorary Title "Friend of the Regional Specialist Children's Hospital in Olsztyn" (2007) for outstanding commitment to the development of pediatric nursing, the Statuette of St. James - the patron saint of Olsztyn - on the sixty-fifth anniversary of university education in Warmia and Mazury for her services aimed at the development of the University of Warmia and Mazury in Olsztyn (2010), Award of the Voivode of Warmia and Mazury named "Woman with Character [Kobieta z Charakterem]" (2010), and Golden Laurels of the University of Warmia and Mazury for her career achievements (2019). Professor Dynowska was also a laureate of the "Golden Ten" Women of Success in Warmia and Mazury (2007), although she does not view her achievements as success. She considers herself lucky to have met wise and kind teachers in her life, frequently mentioning a few names: Eugenia Schneider (her secondary school biology teacher) and Professors Józef Motyka, Bogusław Sałata, Adam Paszewski, Janina Mikołajska (promoter of her doctoral thesis), Alina Skirgiełło, Alicja Kurnatowska, and Eugenia Dyner, who introduced Professor Dynowska to the issues of medical mycology.

Professor Maria Dynowska is generally perceived as a matter-of-fact and resolute person who highly values friendship and good manners. 